\section{APSA Treasurer's Report}

\section{Gary Jacobson, University of California}

Susan Bourque turned over the Treasurer's ciuties to me last year with the Association's finances in excellent shape. I am happy to report that careful budgetary management by the Association's staff and a strong stock market has further strengthened the APSA's financial condition during the past fiscal year. Table 1 shows that from July 1 , 1995, through June 30, 1996, the Association's total assets grew to $\$ 12,052,754$, an increase of $18 \%$ over the previous year. Table 2 summarizes the content of our investment portfolio, which shared the stock market's extraordinary rise during this period. The Trust and Development Fund earned a total return of 28.6\%, the Congressional Fellowship portfolio, $26.4 \%$ (after fees), both outperforming the S\&P 500 index. At the close of fiscal 1995-96, the T\&D fund stood at $\$ 3,248,013$, the Congressional Fellowship and other endowed program funds, at $\$ 9,442,658$, and the Working Capital fund at $\$ 1,090,232$.

APSA rules allow $4.5 \%$ of the market value of the Trust and Development funds to be spent each year on APSA programs. Total retained earnings from all APSA funds, including award funds, contributed $\$ 199,514$ to the Association's work for 1995-96. The Congressional Fellowship endowment funded 8 fellowships and helped to finance 2 others.

Table 3 shows that the Association once again enjoyed a substantial budget surplus. The surplus resulted from the stellar performance of the Association's investments and several one-time savings on the expenditure side. We cannot, of course, count on similar windfalls in future years. Table 4 specifies the revenue sources that produced a total of $\$ 2,882,154$ for $1995-96$. Table 5 summarizes spending by major categories, totaling $\$ 2,590,227$, for a surplus of $\$ 231,927$. Continuing efforts to control costs have clearly succeeded; expenditures rose by only $2.6 \%$ over the previous fiscal year. The
TABLE 1

APSA Balance Sheet

\begin{tabular}{lrrrr}
\hline & \multicolumn{4}{c}{ Total All Funds June 30 } \\
\cline { 2 - 5 } & \multicolumn{1}{c}{1996} & \multicolumn{1}{c}{1995} & 1994 & \multicolumn{1}{c}{1993} \\
\hline Assets: & $11,572,004$ & $9,726,471$ & $9,496,055$ & $8,759,789$ \\
$\quad$ Current & 480,750 & 484,328 & 480,152 & 457,770 \\
$\quad$ Property \& Equipment & & & & \\
Liabilities and Net Assets: & $1,208,790$ & $1,057,642$ & $1,334,913$ & $1,048,376$ \\
$\quad$ Current & $10,843,964$ & $9,153,157$ & $8,641,294$ & $8,169,183$ \\
$\quad$ Net Assets & $12,052,754$ & $10,210,799$ & $9,976,207$ & $9,217,559$ \\
Total: & & &
\end{tabular}

\section{TABLE 2}

Portfolio Summary-General Operating, Trust \& Development, and Endowed Funds, June 30, 1996

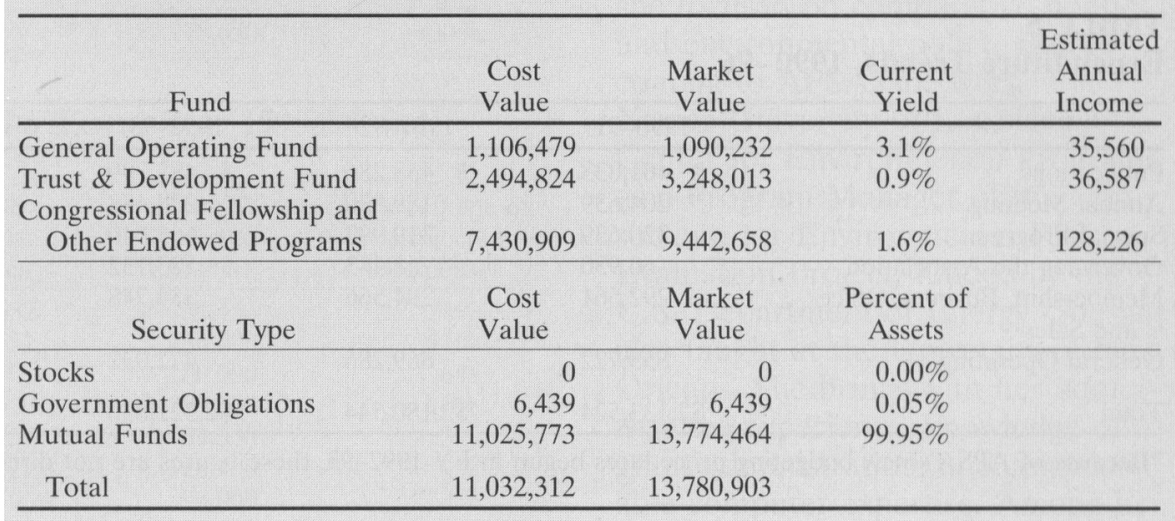

APSA Council has allocated $\$ 30,000$ of the surplus to help support the activities of the Ralph Bunche Summer Institute over the next two years. The remainder has been put in the T\&D fund and earmarked for the Second Century Fund, which will endow a new Centennial Center for Political Science at the APSA's Washington headquarters.

Table 6 outlines the 1996-97 budget adopted by the APSA Council at its August 28th meeting. It projects revenues of $\$ 2,975,650$ and expenses
TABLE 3.

APSA Budget: A Multi-Year Perspective

\begin{tabular}{ccccc}
\hline Year & Income & Expenditures & $\begin{array}{c}\text { Surplus }+ \\
\text { Deficit }-\end{array}$ & $\begin{array}{c}\text { Annual } \\
\text { Expenditure } \\
\text { Change (\%) }\end{array}$ \\
\hline $1983-84$ & $1,323,074$ & $1,247,529$ & $+75,545$ & +14.0 \\
$1984-85$ & $1,413,078$ & $1,353,330$ & $+59,739$ & +8.5 \\
$1985-86$ & $1,505,224$ & $1,453,248$ & $+51,976$ & +6.9 \\
$1986-87$ & $1,584,945$ & $1,449,638$ & $+85,307$ & +3.1 \\
$1987-88$ & $1,637,637$ & $1,563,252$ & $+74,385$ & +4.2 \\
$1988-89$ & $1,847,152$ & $1,731,251$ & $+115,901$ & +10.7 \\
$1989-90$ & $1,891,773$ & $1,871,305$ & $+20,464$ & +14.0 \\
$1990-91$ & $2,153,800$ & $2,133,524$ & $+24,594$ & +2.2 \\
$1991-92$ & $2,254,844$ & $2,180,544$ & $+74,300$ & $-*$ \\
& $2,405,023$ & $2,321,830$ & $+83,193$ & +4.4 \\
$1992-93$ & $2,704,155$ & $2,423,847$ & $+280,308$ & +4.2 \\
$1993-94$ & $2,734,375$ & $2,524,664$ & $+209,711$ & +2.6 \\
$1994-95$ & $2,822,154$ & $2,590,227$ & $+231,927$ & \\
$1995-96$ & & & & \\
\hline
\end{tabular}

*In FY 1992-93, APSA moved to a new budgeting system, making the figures in this year not comparable with previous years. 


\begin{tabular}{|c|c|c|c|c|c|c|}
\hline & 1990-91 & 1991-92 & 1992-93* & 1993-94 & 1994-95 & $1995-96$ \\
\hline Individual Membership & $\$ 650,434$ & $\$ 667,320$ & $\$ 679,663$ & $\$ 744,160$ & $\$ 805,786$ & $\$ 732,439$ \\
\hline Institutional Membership & 380,996 & 395,972 & 399,081 & 410,566 & 434,649 & 448,803 \\
\hline Administrative & 61,281 & 73,772 & 73,421 & 59,143 & 58,095 & 61,263 \\
\hline Annual Meeting Registration & 143,585 & 201,720 & 182,715 & 224,330 & 266,370 & 266,990 \\
\hline Advertising & 280,197 & 296,648 & 307,626 & 285,843 & 340,821 & 338,244 \\
\hline Dividends/Interest & 101,185 & 103,709 & 151,848 & 211,895 & 97,024 & 199,514 \\
\hline Sales/Publications & 138,208 & 130,697 & 166,064 & 231,889 & 212,042 & 227,129 \\
\hline Department Services & 190,146 & 153,405 & 179,648 & 223,219 & 184,918 & 183,239 \\
\hline Other & 212,076 & 231,601 & 264,957 & 313,110 & 334,670 & 364,533 \\
\hline Total & $\$ 2,158,118$ & $\$ 2,254,844$ & $\$ 2,405,023$ & $\$ 2,704,155$ & $\$ 2,734,375$ & $\$ 2,822,154$ \\
\hline
\end{tabular}

*Because of APSA's new budgeting procedures begun in FY 1992-93, these figures are not directly comparable to previous years.

TABLE 5

Expenditure Trends, 1990-96

\begin{tabular}{|c|c|c|c|c|c|c|}
\hline & 1990-91 & 1991-92 & 1992-93* & 1993-94 & 1994-95 & $1995-96$ \\
\hline Publications & $\$ 401,033$ & $\$ 438,286$ & $\$ 487,799$ & $\$ 541,746$ & $\$ 532,219$ & $\$ 561,584$ \\
\hline Annual Meeting & 204,639 & 189,970 & 238,478 & 226,188 & 272,622 & 286,651 \\
\hline Special Programs & 320,639 & 319,993 & 665,640 & 688,587 & 725,885 & 738,856 \\
\hline Governing the Association & 60,930 & 68,443 & 123,132 & 130,992 & 127,964 & 138,768 \\
\hline $\begin{array}{l}\text { Membership, Business Office } \\
\text { and Sales }\end{array}$ & 292,561 & 294,566 & 334,748 & 348,293 & 379,345 & 363,398 \\
\hline General Operating & 853,722 & 869,286 & 472,032 & 488,041 & 486,629 & 500,970 \\
\hline Total & $\$ 2,133,524$ & $\$ 2,180,544$ & $\$ 2,321,830$ & $\$ 2,423,847$ & $\$ 2,524,664$ & $\$ 2,590,227$ \\
\hline
\end{tabular}

*Because of APSA's new budgeting procedures begun in FY 1992-93, these figures are not directly comparable to previous years.

of $\$ 2,974,793$, anticipating a slight surplus (\$857). The major expense increases are in the areas of committee programs (primarily for the Second Century campaign and one additional staff person), the annual meeting, education and professional development (grants that have covered some staff costs may not be renewed), and publications. The proposed budget balances only because of the recent dues increase. Memberships, both individual and institutional, provide $50 \%$ of projected revenue, with the Annual Meeting providing another $17 \%$. Table 7 shows the APSA's salary scale in comparison with the federal government's salary scale equivalents.

APSA's sound financial condition is the result of careful management by Cathy Rudder, Laura Tyson, the rest of APSA's dedicated staff, and of the work of the Trust and Development Board, whose members this year included Barbara Bardes, John Bibby, William Daniels, Larry Dodd, Anne Hopkins, and James Stimson. All of them deserve our gratitude for their service.

\section{New APSA Officers Elected}

At the 92nd Annual Meeting, the slate of officers put forward by the APSA Nominating Committee was unanimously accepted. The 1996-97 officers are:

\section{President:}

Elinor Ostrom, Indiana University

President-Elect:

M. Kent Jennings, University of California-Santa Barbara

\section{Vice Presidents:}

Suzanne Berger, Massachusetts Institute of Technology

William E. Nelson, Jr., The Ohio State University

G. Bingham Powell, University of Rochester

\section{Secretary:}

Virginia Sapiro, University of Wisconsin-Madison

\section{Ralph Bunche Summer Institute Celebrates 10th Anniversary}

Ten 1996 Ralph Bunche Summer Institute participants were honored at the closing ceremony of the Institute in July. The occasion also marked the 10-year anniversary of the Institute.

APSA President Arend Lijphart addressed students on the topic of "Ralph Bunche, Arthur Lewis, and the Quest for Peace and Democracy." Students also heard comments from Paula McClain, chair of the Department of Government and Foreign Affairs at the University of Virginia, and Steve Finkel, who served as director of the Institute and teacher of the Institute's quantitative course. Also in attendance were Avon Drake of Virginia Commonwealth University, who taught the Institute's course on "Race and American Politics," and Frank Scioli of the National Science Foundation.

The five-week, for-credit Institute is designed to introduce African- 